Nigerian Journal of Physiological Sciences 23 (1-2): 79-83 @Physiological Society of Nigeria, 2008

Available online/abstracted at http://www.bioline.org.br/np; www.ajol.info/journals.nips; www.cas.org

\title{
METHANOLIC EXTRACT OF TETRACERA POTATORIA, AN ANTIULCER AGENT INCREASES GASTRIC MUCUS SECRETION AND ENDOGENOUS ANTIOXIDANTS
}

\author{
F. S. OLUWOLE, J. A. AYO, B. O. OMOLASO, B. O. EMIKPE ${ }^{1}$ AND J. K. \\ ADESANWO ${ }^{2}$
}

Department of Physiology, College of Medicine, ${ }^{1}$ Department of Veterinary Pathology, University of Ibadan, and ${ }^{2}$ Department of Chemistry, Obafemi Awolowo University, Ile-ife, Osun-state, Nigeria. E-mail: franwole@yahoo.com

\begin{abstract}
Summary: In this study, the possible mechanism underlying the antiulcer activity of the methanolic extract of the root of Tetracera potatoria (MeTp) was studied in albino rats. Misoprostol and omeprazole were used as reference drugs. The animals had MeTp administered to them at varying doses of 100, 400 and $800 \mathrm{mg} / \mathrm{kg}$ for 15 days. MeTp significantly $(\mathrm{P}<0.05)$ increased gastric mucus secretion and gastric mucus cell counts when compared to control. MeTp treated animals also showed significant $(\mathrm{P}<0.05)$ increase in the activity of superoxide dismutase $(\mathrm{SOD})$ with concurrent decrease in the level of malonialdehyde (MDA) with respect to control. These findings suggest that part of the gastroprotective property of MeTp is associated with the ability of the extract to cause stimulation of gastric mucus secretion through increased number of gastric mucus cells. Increased SOD-activity and decreased MDAlevels further lend support to its gastroprotective effect.
\end{abstract}

Key words: Tetracera potatoria, gastroprotective, gastric mucus secretion, superoxide dismutase

\section{Introduction}

Tetracera potatoria Afzel, family Dillenniaceae is known as liane a eau in France and water tree in Sieerra-leone (Burkil,1985).It is found in wooded areas of Senegal, Southern part of Nigeria, Central and Eastern Africa (Dalziel,1937).

The leaves of the plant boiled in its own sap are used for the treatment of gastrointestinal sores (Burkil, 1985). Adesanwo et al (2003) reported the antiulcer activity of the methanolic extract of the root of Tetracera potatoria. Two doses $(400 \mathrm{mg} / \mathrm{kgBW}$ and $800 \mathrm{mg} / \mathrm{kgBW}$ ) administered to albino rats completely inhibited gastric ulceration and significantly reduced gastric acidity. Previous antiulcer drugs were designed to inhibit gastric acid secretion. However, it is not in all cases of hyperacidity that ulceration develops. Gastric ulcer has been discovered to develop in patients with normal gastric acid output (Lawrence, 2000).

Some other factors implicated in gastric ulcers are oxygen derived radicals, pepsinogen and blood flow (Desai et al, 1997). These radicals are eliminated by the scavenging action of natural antioxidants (Halliwell and Gutteridge, 1990). Some well established endogenous antioxidants are superoxide dismutase, catalase, glutathione reductase and glutathione peroxidase (Kelly, 1998). Flavonoids, another major phytochemical of Tetracera potatoria were reported as effective gastroprotective agents due to their antioxidant activity (Mirossay et al, 1996a, b; 1999).
Though the exact anti-ulcerogenic mechanism of Tetracera potatoria is not fully understood, mucus secretion is regarded as a crucial defensive factor in the protection of the gastric mucosa from gastric lesions (Mallika et al, 2005). In this study, we examined the influence of the methanolic extract of the root of Tetracera potatoria on gastric mucus secretion, gastric mucus cell counts, and the level of production of gastric anti-oxidant enzymes.

\section{Materials and methods \\ Extract preparation:}

Fresh roots of Tetracera potatoria were purchased from Ago-Iwoye, Ogun State, Nigeria and were authenticated by Mr. T.K. Odewo of Forestry Research Institute of Nigeria (FRIN), Ibadan. The roots were air-dried for six weeks, sawn into tiny pieces and later ground, weighing about $5.2 \mathrm{~kg}$. A large quantity $(3.4 \mathrm{~kg})$ of the grinded material was soxhlet-extracted with methanol for about $72 \mathrm{~h}$. The MeTp was then dried in the Gallenhamp oven at $30^{\circ} \mathrm{C}$ for three days. The starting sample gave a mean yield of $7.1 \%$. The extract was reconstituted in distilled water to make up the required concentrations and was stored at $4{ }^{\circ} \mathrm{C}$ until use.

Animals:

Adult Wistar strain rats (180-220g) obtained from the Pre-Clinical Animal house, College of Medicine, University of Ibadan, were used for this study. There were four experimental study groups namely; gastric mucus secretion, gastric mucus cell count, superoxide 
dismutase activity and malondialdehyde level. Control animals were not given any treatment but were fed normally and given water ad libitum. MeTptreated rats were given MeTp at different doses $(100 \mathrm{mg} / \mathrm{kg} \mathrm{BW}, 400 \mathrm{mg} / \mathrm{kg} \mathrm{BW}$ and $800 \mathrm{mg} / \mathrm{kg} \mathrm{BW})$ for 15 days. Some rats pretreated with Omeprazole $(0.67 \mathrm{mg} / \mathrm{kg})$ and Misoprostol $(0.875 \mu \mathrm{g} / \mathrm{kg})$ served as positive controls.

\section{Drugs used}

Chemicals used were Adrenaline, Magnesium chloride (sigma), Carbonate buffer (sigma), Potassium chloride (sigma), Thiobarbituric acid (sigma), Trichloroacetic acid (sigma), Sodium acetate and Alcian blue. Stock solutions were prepared in distilled water.

\section{Determination of gastric mucus secretion}

Gastric mucus secretion was estimated using the earlier method described by Oluwole et al, (2007) after two weeks of pretreatment with the drugs.

\section{Gastric mucus cell count}

The gastric mucus cells were counted using an improvised calibrated microscope. This was an improvement over the foremost blind manner approach for counting (Li et al, 2002). Twenty-five squares, each measuring $2 \mathrm{~mm}$ by $2 \mathrm{~mm}$, were drawn faintly on a transparent nylon. The nylon was then affixed onto the eyepiece of the microscope. The gastric mucus cells were counted as cells that stained for Haematoxylin and Eosin indicated as red patches. The mucus cells were counted in five squares during each view. The number of gastric mucus cells in each microscopic view was recorded and the mean number of gastric mucus cells in each square millimeter of gastric tissue was calculated.

\section{Determination of superoxide dismutase activity}

The assay method involves the inhibition of autooxidation of adrenaline to adrenochrome by SOD. The rate of autoxidation of adrenaline and the sensitivity of this inhibition of autooxidation by SOD were both augmented as the $\mathrm{pH}$ was raised from $7.8-$ 10.2. The animals were bled through the eye and the blood samples were centrifuged in a cold centrifuge. Plasma samples were stored at $4{ }^{\circ} \mathrm{C}$ until use. $0.2 \mathrm{ml}$ of the test sample was added to $2.5 \mathrm{ml}$ of $0.05 \mathrm{M}$ carbonate buffer. It was allowed to equilibrate in the spectrophotometer. $0.3 \mathrm{ml}$ of freshly prepared $0.3 \mathrm{mM}$ adrenaline was added to the buffer-supernatant mixture, which was quickly mixed by inversion. The reference cuvette contained $2.5 \mathrm{ml}$ of the buffer, $0.1 \mathrm{ml}$ of adrenaline and $0.2 \mathrm{ml}$ of water. The increase in absorbance at $480 \mathrm{~nm}$ was monitored every 30 seconds for 150 seconds.
Calculation:

Change in absorbance $/ \min (\Delta \mathrm{A} / \mathrm{min})=\mathrm{A} 2-\mathrm{A} 1$

Where A2 = Final absorbance after 150 seconds

A1 = Initial absorbance after 30 seconds $\mathrm{t}=2.5 \mathrm{~min}$

$\%$ inhibition $=\underline{1-(\Delta \mathrm{A} \text { Sample } / \mathrm{min}) \times 100}$

$$
\triangle \mathrm{A} \text { blank } / \mathrm{min}
$$

$\Delta \mathrm{A}$ blank $/ \mathrm{min}=$ constant $=0.025 / \mathrm{min}$

Using the above calculations, a standard curve for SOD activity was plotted and the percentage SOD activity of each experimental group was deduced from the curve.

\section{Estimation of lipid peroxidation}

Lipid peroxidation was assessed by the method described by Gutteridge and Wilkins(1982), This is based on the reaction between 2-thiobarbituric acid (TBA) and malonialdehyde(MDA) which is the endproduct of lipid peroxidation.

\section{Statistical analysis}

Results were expressed as Mean \pm SEM. Statistical analysis was performed using student's ttest and significant differences were accepted at $\mathrm{P}<0.05$.

\section{Results}

Gastric mucus secretory activity

From Table 1, the mean gastric mucus secretion in control animals was $4.16 \pm 0.08$ as against $4.55 \pm 0.09,6.44 \pm 0.13$, and $5.67 \pm 0.08$ in low dose, medium dose and high dose pretreated animals respectively. The observed increase with each of the doses was significant $(\mathrm{P}<0.05)$ Similarly, Misoprostol significantly increased gastric mucus secretion compared with the control $(\mathrm{P}<0.05)$. However, omeprazole significantly reduced gastric mucus secretion comparable to control $(\mathrm{P}<0.05)$.

\section{Effect of Tetracera potatoria on gastric mucus cell counts}

Methanolic extract of Tetracera potatoria significantly increased the number of mucus cell count in animals pretreated with medium dose (MD) and High dose (HD) when compared with the mean value obtained from the control rats (Table 2) $(\mathrm{P}<0.05)$. There was however, a significant reduction in low dose (LD) animals. Omeprazole and Misoprostol at various doses used caused significant increase in gastric mucus cell counts compared to control $(\mathrm{P}<0.05)$. 
Table 1: Mean gastric mucus secretion in control and animals treated with Methanolic extract of the root of Tetracera potatoria (MeTp)

\begin{tabular}{ccc}
\hline Animal Treatment & $\begin{array}{c}\text { No of } \\
\text { Animals }\end{array}$ & $\begin{array}{c}\text { Gastric mucus } \\
\text { secretion }(\mathrm{mg} / \mathrm{g}) \\
\text { Mean } \pm \text { S.E.M }\end{array}$ \\
$\begin{array}{c}\text { Control (non-treated) } \\
\text { Low-dose }\end{array}$ & 5 & $\begin{array}{c}4.16 \pm 0.08 \\
4.55 \pm 0.09^{*}\end{array}$ \\
$\begin{array}{c}(100 \mathrm{mg} / \mathrm{kg}) \\
\text { Medium-dose } \\
(400 \mathrm{mg} / \mathrm{kg})\end{array}$ & 5 & $6.44 \pm 0.13^{*}$ \\
$\begin{array}{c}\text { High Dose } \\
(800 \mathrm{mg} / \mathrm{kg})\end{array}$ & 5 & $5.67 \pm 0.08^{*}$ \\
$\begin{array}{c}\text { Omeprazole } \\
(0.67 \mathrm{mg} / \mathrm{kg})\end{array}$ & 4 & $2.61 \pm 0.02^{*}$ \\
$\begin{array}{c}\text { Misoprostol } \\
(0.875 \mu \mathrm{g} / \mathrm{kg})\end{array}$ & 4 & $5.54 \pm 0.02 *$ \\
\hline
\end{tabular}

$\mathrm{P}$-value at $\mathrm{P}<0.05 *$ Significantly different from control.

Table 2: The mean gastric mucus cell count $\left(\mathrm{mm}^{2}\right)$ in control and animals treated with the Methanolic Extract of the Root of Tetracera potatoria (MeTp)

\begin{tabular}{ccc}
\hline Group Treatment & $\begin{array}{c}\text { No of } \\
\text { Animals }\end{array}$ & $\begin{array}{c}\text { Gastric mucus } \\
\text { cell } \\
\text { count }\left(\mathrm{mm}^{2}\right) \\
\text { Mean } \pm \text { SEM }\end{array}$ \\
Control (non-treated) & 5 & $1.98 \pm 0.00$ \\
Low-dose $(100 \mathrm{mg} / \mathrm{kg})$ & 5 & $1.83 \pm 0.01 *$ \\
Medium-dose $(400 \mathrm{mgkg})$ & 5 & $2.34 \pm 0.02 *$ \\
High dose $(800 \mathrm{mg} / \mathrm{kg})$ & 5 & $2.93 \pm 0.00 *$ \\
Omeprazole $(0.67 \mathrm{mg} / \mathrm{kg}$ & 5 & $2.09 \pm 0.05 *$ \\
Misoprostol $(0.875 \mu \mathrm{g} / \mathrm{kg})$ & 5 & $2.08 \pm 0.01 *$ \\
\hline P-value at $\mathrm{P}<0.05 . \quad *$ Significantly different from \\
control.
\end{tabular}

Effect of Tetracera potatoria on Superoxide dismutase (SOD) activity

Methanolic extract of Tetracera potatoria increased SOD activity in a dose dependent fashion in all the groups (Table 3). The increase demonstrated in each group was significant conpared to the control $(\mathrm{P}<0.05)$.

Effect of Tetracera potatoria on malonialdehye concentration

The extract reduced the concentration of assayed maloniaaldehye from $1.888 \pm 0.011$ in the control to $1.714 \pm 0.009$ (LD), $1.561 \pm 0.005$ (MD) and $1.304 \pm 0.005$ (HD). The reduction in the MD and HD pretreated animals were significant $(\mathrm{P}<.0 .05)$. This is illustrated in Table 4.

Table 3: The Mean superoxide dismutase activity in $(\mu \mathrm{g} / \mathrm{ml})$ control and animals treated with Methanolic Extract of the root of Tetracera potatoria (MeTp).

\begin{tabular}{lll}
\hline Group Treatment & $\begin{array}{l}\text { No of } \\
\text { Animals }\end{array}$ & $\begin{array}{l}\text { Superoxide } \\
\text { dismutase } \\
\text { activity }(\mu \mathrm{g} / \mathrm{ml}) \\
\text { Mean } \pm S E M\end{array}$ \\
$\begin{array}{l}\text { Control (non-treated) } \\
\text { Low-dose }(100 \mathrm{mg} / \mathrm{kg})\end{array}$ & 5 & $19.90 \pm 1.25$ \\
$\begin{array}{l}\text { Medium- } \\
\text { dose }(400 \mathrm{mg} / \mathrm{kg})\end{array}$ & 5 & $21.86 \pm 0.64 *$ \\
High Dose $(800 \mathrm{mg} / \mathrm{kg})$ & 5 & $49.08 \pm 1.50 *$ \\
\hline $\begin{array}{l}\text { P-value at } \mathrm{P}<0.05 . \\
\text { control. }\end{array}$ & Significantly different from \\
\hline
\end{tabular}

Table 4: Mean malonialdehyde concentration in control and animals treated with the Extract of the root of Tetracera potatoria (MeTp)

\begin{tabular}{ccc}
\hline $\begin{array}{c}\text { Group } \\
\text { Treatment }\end{array}$ & $\begin{array}{c}\text { No of } \\
\text { Animals }\end{array}$ & $\begin{array}{c}\text { Malonialdehye } \\
\text { concentration } \\
\left(\mu \text { mol/l) } x 10^{-6}\right. \\
\text { Mean } \pm \text { SEM }\end{array}$ \\
$\begin{array}{c}\text { Control } \\
\text { (non-treated) } \\
\text { Low-dose }\end{array}$ & 5 & $1.888 \pm 0.011$ \\
$\begin{array}{c}(100 \mathrm{mg} / \mathrm{kg}) \\
\text { Medium-dose } \\
(400 \mathrm{mg} / \mathrm{kg})\end{array}$ & 5 & $1.714 \pm 0.009$ \\
$\begin{array}{c}\text { High dose } \\
(800 \mathrm{mg} / \mathrm{kg})\end{array}$ & 5 & $1.561 \pm 0.005^{*}$ \\
\hline $\begin{array}{c}\text { P-value at } \mathrm{P}<0.05 . \\
\text { control. }\end{array}$ & *Significantly different from \\
\end{tabular}

\section{Discussion}

The role of MeTp as an antiulcer agent had earlier been reported by Adesanwo et al (2003), having discovered a reduction in gastric acidity in animals treated with MeTp. Acute pretreatment of rats with MeTp and Misoprostol (15days) caused significant increase in gastric mucus secretion in all doses administered $(100,400$, and $800 \mathrm{mg} / \mathrm{kg})$ in comparison to $4.16 \pm 0.08 \mathrm{mg} / \mathrm{g}$ in the control group $(\mathrm{P}<0.05)$. However, omeprazole, a proton pump inhibitor significantly reduced gastric mucus secretion $(\mathrm{P}<0.05)$. Gastric mucus cells counts also increased significantly at doses of 400 and $800 \mathrm{mg} / \mathrm{kg}$ compared with the control (Table 2) $(\mathrm{P}<0.05)$. This 
finding is indicative of the fact that MeTp enhances the growth of mucus secreting cells and thus agree with the report of Mojzis et al. (1995) that gastric mucus is an important factor in gastric mucosal defense. Other reports of the gastro-protective property of mucus opined that a decrease in gastric mucus secretion renders the mucosa more susceptible to injury induced by various factors with the converse being very correct (Nosalova et al, 1991; Farre et al, 1995).

These stimulatory effects of MeTp on gastric mucus cells and gastric mucus secretion may be similar to that of known drugs such as sucralfate and misoprostol (Slomiany et al, 1991, Takahashi and Okabe, 1996). Percentage increase in gastric mucus has been reported to be associated with graded doses of misoprostol in man (Wilson et al, 1986). Misoprostol, by virtue of its ability to stimulate mucus secretion, is an anti-ulcer agent in man (Poonam et al, 2003). Cellular antioxidant enzymes such as superoxide dismutase, glutathione peroxide and catalase normally challenge oxidative stress. In this study, MeTp significantly increased the concentration of superoxide dismutase (an antioxidant enzyme) from $19.90 \pm 1.25$ in the control to $49.40 \pm 4.40$ in high dose treated animals $(\mathrm{P}<0.05)$. Increasing doses of MeTp (LD, MD and HD) significantly decreased the level of malondialdehyde (MDA), a marker of lipid peroxidation $(\mathrm{P}<0.05)$. The findings support other studies that demonstrated a reduction in lipid peroxidation of the gastric mucosa shown to be associated with increased activities of antioxidant enzymes (Melchiorri et al, 1997; Dela et $a l, 1999)$.

The mechanism of action of MeTp in ameliorating ulcer might be due to increased gastric mucus secretion as a result of increased number of gastric mucus cells through cell-proliferation, a mucogenic effect. The extract raises the concentration of one of the primary endogenous enzymes; superoxide dismutase which improves free radical scavenging property in the stomach.

\section{References}

Adesanwo J.K; Ekundayo O; Oluwole F.S; Olajide O.A; Van Den Berge, A.J.; Findlay J.A (2003): The effect of Tetracera potatoria Afzel and its constituent-betulinic acid on gastric acid secretion and experimentally-induced gastric ulceration. Niger. J. Physiol. Sci. 22:21-25.

Burkill, H.M. (1985): The useful plants of West Tropical Africa. $2^{\text {nd }}$ Edition. Royal Botanic Gardens, Kew. 1:650-652.

Dalzel JM (1937): The useful parts of West Tropical Africa. London: Crown Agent Publication.
Dela Lastra AC, Motilva MJ (1999): Protective effects of melatonin on indomethacin-induced gastric injury in rats. J Pineal Res. 26 101-107.

Desai J. K, K. Goyal and R. Parmer, (1997) Pathogenesis of peptic ulcer disease and current trends in therapy. India J. Physiol. Pharmacol. 41: 3-15.

Farre A.J, Colombo M, Alvarez I, Glavin G.B, (1995). Some novel 5-hydroxytryptamine 1A $\left(5-\mathrm{HT}_{1 \mathrm{~A}}\right)$ receptor against reduce gastric acid and pepsin secretion, reduce experimental gastric mucosal injury and enhance gastric macus in rats. J Pharmacol Exp Ther 272: 832837.

Gutteridge J.M.C. and Wilkins C. (1982): Copperdependent hydroxyl radical damage to Ascorbic Acid: Formation of a thiobarbituric acid reactive product. FEBS Lett. 137:327-340.

Halliwell B and Gutteridge, J.M.C (1994): Lipid peroxidation, oxygen radicals, cell damage and antioxidant therapy. Lancet 1: 1396.

Lawrence Werther (2000) Gastric mucosa barrier. Mount Sinai J. Med. 67 (1):41.

Li M, Piero D. S. and John L. (2002): Divergent effects of new cyclooxygenase inhibitors on gastric ulcer healing: Shifting the angiogenic balance. Pharmacology 99: 13243-13247.

Mallika J, Mohan KV and Shyamala Dev, CS (2005): Gastroprotective effect of Cissus quadrangulasis extracts in rats with experimentally induced ulcers. Indian. J. Med Res. 123: 799-806.

Melchiorri D, Sewerynek E, Reiter RJ, Ortiz GG, Poeggeler B, Nistisco G (1997). Suppressive effect of melatonin administration on ethanolinduced gastroduodenal injury in rats in vivo $\mathrm{Br}$ J Pharmacol: 264-270.

Mirrossay L, Kohuta, and Mojzis J (1999). Effect of malotilate on ethanol-induced gastric mucosal damage in caposaicin-pretreated rats. Physiol Res 48: 375-381.

Mojzis J, Kohut A, Mirossay L, Nicak, Pomfy M, Benicky M, Bodnar J (1995): Effect of sucralfate on ischemia/reperfusion -induced gastric mucosal injury. Slovakofarma Rev 5: 5357.

Nosal'ova V, Juranek I, Babulova A (1991). Effect of pentacaine and ranitidine on gastric mucus changes induced by cold-restraint stress in rats. Agent Action 33: 164-166.

Oluwole F.S, Omolaso B.O and Ayo J.A (2007): Methanolic extract of Entandrophragma angulense induces gastric mucus cell counts and gastric mucus secretion. J. Biol Sci. 7(8): 15311534. 
Antiuler effect of Tetracera potatoria

Poonam D., Vijay K., Surdhir Srivastava, Gautam Palit. (2003). Ulcer healing effects of antiulcer agents: A comparative study. Internet Journal of Academic Physician Assistants. 2(2):

Slomiany BL, Piotrowski J, Tamura S, Slomiany A (1991): Enhancement of the protective qualities of gastric mucus by sucralfate: role of phosphoinositides. Am J Med 91: S30-S36.
Takahashi S, Okabe S (1996.): Stimulatory effects of sucralfate on secretion and synthesis of mucus by rabbit gastric mucosal cells. Involvement of phospholipase C. Dig Dis Sci. 41: 498-504. 